\title{
English Blends in Indonesian Context: Their Formation Processes and Meanings
}

\author{
Rio Rini Diah Moehkardi \\ Department of Language and Literature, Universitas Gadjah Mada, Indonesia \\ Email: riomoehkardi@ugm.ac.id
}

\begin{abstract}
This research aims at observing the blending process, the patterns of blending, and the possible new meanings of the English-influenced blends found in the Indonesian context. The influence of English and Indonesian not only in terms of the source words involved, but also of the morphological processes of the blends and also to see whether there are some semantic changes, anticipating the cultural influence of the blend creators. Data are collected from advertisement of schools events, brand name of food and beverage products, also names of cafes and restaurants found mostly in Yogyakarta. The data are analyzed using Mattiello's formula (2013) in categorizing the process of blending: morphotactical, morphonological, and morphosemantic. The results show that morphotactically the data can be classified into total and partial blends of which there are more blends whose first source words are kept full and followed by clipped second source words. In morphopohonological process, there is no non-overlapping blends; phonological overlap also takes place, but not orthographical one. Morphosemantically, attributive blends are more frequent than the coordinative ones.
\end{abstract}

Keywords: blending; formation process; meaning; Indonesian context

\section{INTRODUCTION}

Bahasa Indonesia (BI) is an official language introduced to preschoolers and still taught to university students, used at homes to most households in urban areas in Indonesia, yet as a relatively young and dynamic language, especially the vocabulary of Bahasa Indonesia is very much influenced by many other languages, both outside and inside the country.

Bahasa Indonesia has many loanwords in its lexicon. To name only few here are some foreign words borrowed in Bahasa Indonesia: adakala (BI) meaning sometimes is from Hindi kâda kalâ; akad (BI) meaning promise is from Arabic aqd and many others from local languages: cengang (BI) meaning amazed is from Minang language cangang; anjlok (BI) meaning drop is from Javanese anjlok.

As a dynamic language BI practices wordformation processes to enrich its vocabulary, among of which is blending. Blends can be found almost anywhere in Indonesian context, both written and spoken, in the national and indigenous languages. Some blends are regarded informal, and some others are so well accepted that they are used in more formal situations. For example in Bahasa Indonesia, blends: pemilu (pemilihan + umum--general election) and pilkada (pemilihan + $k$ epal $a+$ daerah--regional head election) are among well accepted blends and regarded as formal. People use the blends and not the full phrases in any situation.

Blending is one of word formation processes naturally occurs in many languages, such as English (workaholic from work $+\mathrm{a}(\mathrm{lco})$ holic); Bahasa Indonesia (Orba from orde + baru -- new order; pemprov from pemerintah + provinsi -- provincial government) even Javanese, one of Indonesian local indigenous languages also practices this word formation (nasgitel from panas 
+ legi + kentel meaning hot + sweet + strong; indicating strong, sweet and hot tea or coffee).

English also gives some influence in BI, not only loanwords but also many blends found in Yogyakarta, Indonesia are of English influence. Although there are many English loan blends in Bahasa Indonesia, such as teenlit, vlog, workaholic, chocolicious, etc. there are many blends created by Indonesian speakers; many of them are names of school events, music performance, cafes or restaurants, food and beverages products.

Unlike, many Indonesian-word blends, English blends found in Yogyakarta, Indonesia, are mostly found in advertisement. The popular creation of blends in Indonesia, Yogyakarta in particular, seems to resonance Steinmetz and Kipfer's sentiment in favor of acronyms, clipping and blending as more popular word formation processes due to their catchiness, economy, and humour compared to compounding and derivation (2006 in Fadrych, 2008) and echoing Algeo's (1977, p. 61) that blends " are coined not alone for their usefulness, but partly, and in some cases principally, for their cleverness." It is the clever and funny aspect of blending that renders an attractive process, not only to linguists, but also to advertising executives, script writers...(in Danks, 2003, p. 2). Danks furthermore suggests that most blends "are ephemereal; they are coined for particular purposes and once the purpose has gone then the word is no longer needed." (Danks, 2003, p. 3). Blends may live shortly, yet many new ones are born in many more creative ways.

This paper aims at analyzing the formation-process of English blends in Indonesian context and their meaning will be observed to see the influence of both English and $\mathrm{BI}$ in the blends, not only in terms of the source words involved, but also of the morphological process of the blends and also to see the relations between the source words involvement in the blend and the semantic change, anticipating the cultural influence of the blend creators.

\section{THEORETICAL FRAMEWORK}

Although blends have been in use further back in Shakespeare's time and have been studied extensively since the twentieth century (Algeo, 1977, p. 47), definitions of blending and blending categories have not yet set.

The term "blending" has been used in a number of ways, usually to denote a word formation process which combines two source lexemes, at least one of which has been shortened in the combination, sometimes with a graphic and /or phonological overlap (Mattiello, 2013, p. 112). Beliaeva confirms in her research that blending involves at least 2 or more source words, nonmorphematic formation, clipping of the source words, coordinative relation between source words, phonic integration, and overlap (2014: appendix, table 1). Her confirmation is based on previous studies in the area by various linguists.

Kreidler's definition of blending (1994 in Fandrych, 2008): "Sometimes two words are clipped simultaneously and united to form a 'blend'. The two source words may be syntagmatically related or paradigmatically related." Kubozono (1990, in Mattiello, 2013, p. 113) sees the relations of the source words, of blends that are in paradigmatic relations, such as chofa (chair + sofa) or syntagmatic relations, such as porta-light (portable + light). Other linguists (Cannon, 2000; Plag, 2003; and Bat El, 200 in Mattiello, 2013, p. 114) also see that the source words often exhibit some semantic similarity but " rarely synonyms," such as brunch (breakfast + lunch); usually "belong to the same syntactic category" (Kubozono, 1990, in Mattiello, 2013, p. 114), such as adjective + adjective : ginormous (gigantic + enormous) or show some "phonological similarity" (Cannon, 2000, in Mattiello, 2013, p. 114), such as hesiflation (hesitation + inflation).

Whereas, Plag (2003) offers rather narrow definition of blend that "it is always the first part of the first element that is combined with the second part of the second element" that is similar to that of Bat El (2006, in Mattiello, p. 113) "blends refer only to cases where the inner edges are truncated," Gries (2004) observes more in the process of blending that "involves the coinage of a new lexeme by fusing parts of at least two other source words of which either one is shortened in the fusion and or where there is some form of phonemic or graphemic overlap of the source words." Overlapping graphemes and phonemes in blend actually distinguish blend from acronym. The following is the distinction between blending and other similar word formations: acronym, clipping and compounding.

Acronym and blending are often confused as of the same processes (Stockwell and Minkova, 2001 in Fandrych, 2008; Permata and Suyudi, 2011), both processes in creating a new lexeme require at least two lexemes, both undergo cut in some part of the member lexemes. However, in acronym, the new lexeme consists of the first phoneme or grapheme of the source words, although sometimes in order the new lexeme can be pronounced as a word, not only does the initial sounds are taken but sometimes the next first consonant and first vowel. In blending, usually there are more graphemes or phonemes of the source words involved in forming a 
pronounceable blend (Fandrych, 2008).

Whereas truncation in clipping is rather clear cut, that in acronyms and blends are often less than a syllable. Hozzeinzadeh (2014) regards the parts clipped or overlapped as bits (“... new blend created by using the first bit of the first word, the last bit of the second one"), however, some other linguists, such as Berman (1961), Adam (1973) in Fandrych (2008), and Bauer (2006 in Believa, 2014, p. 49) regard them as splinters. Furthermore, Bauer notes that splinters refer to word parts that have been frequently used in forming blends, such as (-holic; -nomic), and, some other linguists regard them as 'bound morpheme' (Lehrer, 1998), combining form (Lehrer, 1988; B Warren, 1990), or bound splinter (Fandrych 2008a in Believa, 2014, p. 49). Believa (2014, p. 49-50) proposes that splinters are parts of words that make the blends, on condition that they are not full words and not morphemes or bound morphs accepted in dictionaries.

Soudek (1978 in Fandrych, 2008) develops the term into: "initial splinter" and "final splinter," referring to the first or second element of the blend for the former, and only the second element of the blend for the latter. Rua (2002 in Fandrych, 2008) defines "splinter" as graphic and phonemic sequence which are neither inflectional nor derivational morphemes, nor combining forms, and whose length generally allows their identification as belonging to a previous word. Splinters tend to be syllable or larger than syllables in their sources. When they are shorter than syllables, their constituents are a. the syllable onset (the prevocalic consonant or consonant); $b$. the onset and the nucleus (prevocalic consonants and vowel); c. the rhyme (vowel + postvocalic consonant or coda) (Rua, 2002 in Fandrych, 2008). Danks (2003, p. 19) confirms that the term "splinter" is used to describe "bits" from the source words truncated that appear in the blends. However, she reminds that blending may not only use splinter, but may also two words overlapped, such as Japanimation (Japan + animation).

As the parts shortened in the source words in blending process often "include unpredictable splinters instead of existing morphemes" (Soudek, 1978 in Danks 2003 , p. 11), blending usually is classified as the nonmorphematic word-formation (Fandrych, 2008), and thus labelled as "extra grammatical morphology," a term introduced by Dressler and Merlini Barbressi (1994 in Mattiello 2013, p. 1) referring to word formations "through which the process obtained are not identifiable and the input does not allow a prediction of regular input."

The fact that it takes at least two source words in blending reminds us of compounding: "the process of putting two words together to form a third" (Bauer, 1983 in Danks, 2003, p. 47). Lehrer (2007 in Mattiello, 2013, p. 113) states that "blends are underlying compounds which are composed of one word and part of another, or parts of two (occasionally three) other words." CarstairsMcCarthy (2002, p. 65) says that blends "are a kind of compound where at least one component is reproduced only partially." Furthermore, Kemmer (2003 in Mattiello, 2013, p. 114) points out that what distinguish blends from compounds is that "they (blends) combine parts of lexical source words, rather than the whole source words".

Similar to compounding that can be written as a simple word (paperclip), with a space (paper aeroplane) or include a hyphen (oil-paper), although most blends are written as simple words, some blends are found with hyphen (rap-sploitation, porta-light). Furthermore, although rarely, they may be written with a space (docu drama). Both compound and blend, once formed, become the base to which affixes attach: blue-eyed, bookkeeper, sky-diving in compounding and sexploiting, chortled, electrocution in blending (Danks, 2003, pp. 48-49). Unlike compound, which is self-defining, some blends do not explain themselves when out of context, for example: cyxploitation and probot (Danks 2003, p. 50). Moreover, whereas compounding reproduces the whole component words, in blending at least one word is reproduced partially and can come from non-words too, for example aquarobics blends splinter and neo-classsical combining forms (aqua + aerobics).

Ingo Plag classifies blends (2002, pp. 155-160) in two types: abbreviated compound and proper blend. The former is originally a compound whose meaning is mostly determined by the second element (the head), for example: breath analyzer - breathalyzer - is a kind of analyzer; science fiction-sci-fi, a kind of fiction; when they are shortened, they retain their meaning as compound. This type, in other classification, is referred to as syntagmatic origin (Bauer, 2012 in Believa 2014, p. 30), one of the source words, usually the second or the right one, is the head and the first is the modifier. However, the latter's source words, for examples, boat + hotel; breakfast + lunch, when they are shortened - boatel and brunch, they denote the referents of both source words, resembling the copulative compound, or considered as paradigmatic origin (Bauer, 2012 in Believa 2014, p. 30): both words are heads. Mattiello (2013, pp. 123-125) refers abbreviated compound to attributive blend of which its second word source functions as head and the first as modifier; whereas, the proper blend, is called coordinate blend of which the two word sources are related syntactically and semantically. 
Syntactically, the source words paradigmatically belong to the same syntactic category. Semantically, the source words are usually co-hyponyms of a more general term (capcin - cappuccino + cincau) or combination of synonyms (attractivating - attractive + captivating). Furthermore, Mattiello (2013, p. 124) also suggests that most coordinate blends are endocentric.

Not only are definitions various, earlier linguists (including Algeo, 1977; Soudek, 1978; Cannon, 2000; Kemmer, 2003; Ronneberger-Sibold, 2006, Lehrer, 1996 and 2007 in Mattiello, 2013, p. 118), Quirk (1985) and more recent ones such as, Fandrych, (2008), Mattiello (2013) and Hozzainzadech (2014) have proposed various classifications demonstrating many parameters in combining patterns of blending. Whereas Quirk (1985), Fandrych (2008) and Hozzainzadech (2014) focus on structural classification of blend formation, Algeo (1977) also includes systematic categories and Mottiello (2013) morphosemantic categories referring to the semantic relations of the source words.

Algeo (1977, pp. 49-55 and 55-61) classifies blending into structural categories, dealing with how blends are formed and systemic categories dealing with the relationship of the source words. The structural categories include: blends with overlapping, blends with clipping, clipping at morpheme (syllable) boundaries, blends with clipping and overlapping. The systemic categories include syntagmatic blends, associative blends: synonymic, paradigmatic, jumble, indefinite composites, telescope and portmanteau. Whereas, Algeo (1977) includes the significance of relationship of the source words, Quirk (1985), Fandrych (2008) and Hozzainzadech (2014) focus on structural categories of blending which are more or less similar.

\section{DATA AND METHODOLOGY}

The data of this research are taken from advertisement of school events, name of food and beverage products, name of restaurants or cafes found mostly in Yogyakarta, but some are also found in magazine, stores (especially, the names of food and beverage products). The data (80 blends) were collected from April - November 2017. Including blends with similar morphemes and formation process are counted individually, for example there are 6 blends with-licious morpheme following the unshortened first words, as each in fact has different initial source word. The term 'source words' is used to refer to the lexical units in the blend, including the bound roots or combining forms (Carstairs-McCarthy, 2002, p. 66), such as anthropo- and -logy also new morphemes resulted from blending (Algeo, 1977, p. 52), such as cast that has the noun sense of broadcast, -athon from marathon. However, the term 'source-form' is used for non-words, such as the use of affix (Belieava, 2014, p. 4), the present research also uses this term for abbreviation, such as FIB and MUF. The term 'splinter' is used in this current discussion rather than 'part' (Quirk, 1985) or 'bit' (Hozzainzadech, 2014). In presenting the data, the researcher uses italic for the blend; symbol + indicating the source words, the origin of the blend; ( ) indicating the part of the word that is clipped, shortened, or cut; bold indicating overlap, for example: biolympic - biol(ogy) + olympic and underline indicating embedded splinter in one of the source word: autopathography-auto(bio) graphy + patho $(\operatorname{logy})$.

This research follows Mattiello's formula in categorizing blending (2013). It distinguishes blends into three categories of which 2 are in the formation processes : a. morphotactical classifies blends into total blends where all source words are reduced in splinters, and partial blends where only one source word is reduced; and, b. morphonological and graphical systems distinguish blends into overlapping and non-overlapping; and another category on morphosemantic observing the semantic relation between the source words: attributive and coordinate blends

There is not any data in the current research that fit 1 sub-categories of total blends in morphotactical classification: blends made from both splinters that are the end of the source words (Kongfrontation-(King) Kong $+($ con)frontation. Furthermore, there is not any data that fit 1 sub-category of overlapping in morphonological and phonological category: the constituents overlap orthographically but not phonologically, for example: smog - smo $(\mathrm{ke})+(\mathrm{f}) \underline{\mathrm{og}}$ the shared letter $/ \mathrm{o} /$ is pronounced $/$ ov/ in smoke but $/ \mathfrak{p} /$ in fog.

\section{DISCUSSION}

Mottiello divides blend morphotactically into two types: a) total blends (all source words are reduced in splinter) and b) partial blends (only one source word is reduced). The following is how the current data are categorized.

\section{Morphotactical}

\section{Total blends}

Total blends are those in which all source words are reduced to splinters; there are 4 sub-categories of this.

a. The beginning of one word is followed by the end of another: Oxbridge-- Ox(ford) + (Cam)bridge 


\begin{tabular}{|c|c|c|}
\hline blends & & Constituents and process \\
\hline Chocoberry & $\rightarrow$ & Choco(late) $+($ straw $)$ berry \\
\hline Robominton & $\rightarrow$ & $\operatorname{Robo}(\mathrm{t})+(\mathrm{bad})$ minton \\
\hline Fooshion (market) & $\longrightarrow$ & Foo $(\mathrm{d})+(\mathrm{fa})$ shion \\
\hline Fashound & $\longrightarrow$ & Fash(ion) $+($ s)ound \\
\hline Chitato & $\longrightarrow$ & Chi(ps $)+($ po $)$ tato \\
\hline Lovamil* & $\longrightarrow$ & $\operatorname{Lov}(\mathrm{e})+(\mathrm{h}) a m i l$ \\
\hline Jogjacation & $\rightarrow$ & Jogja(karta) $+($ edu $)$ cation \\
\hline Idenesia & $\rightarrow$ & Ide(a) $+($ Indo)nesia \\
\hline Sociophoria* & $\rightarrow$ & Socio(logy) $+(\mathrm{eu})$ phoria \\
\hline Sociopreneur & $\rightarrow$ & Socio $*+($ entre $)$ preneur \\
\hline Ebotec & $\rightarrow$ & $\begin{array}{l}E(\text { LINS })+(\text { Ro }) b o t+ \\
\mathrm{eC}(\text { ompetition }\end{array}$ \\
\hline Chernival & $\rightarrow$ & Ch(emical) e-(ca)r (car)nival \\
\hline Pasco* $^{*}$ & $\longrightarrow$ & $\operatorname{Pas}($ sion $)+($ cho $) \operatorname{co}($ late $)$ \\
\hline Instafluences & $\longrightarrow$ & Insta $($ gram $)+$ (in)fluences \\
\hline Agriventor & $\longrightarrow$ & Agri(culture $)+($ in) ventor \\
\hline Anthropocene & $\rightarrow$ & Anthropo(logy) + (s)cene \\
\hline Goviesta & $\longrightarrow$ & $\operatorname{Gov}($ ernment $)+($ F)iesta \\
\hline Tusning* & $\longrightarrow$ & Tues(day) + (eve)ning \\
\hline
\end{tabular}

All of the blends of this sub-type are nouns. From the data above, only one blend (Lovamil) has BI word source: $\operatorname{Lov}(\mathrm{e})+(\mathrm{h})$ amil meaning pregnant. The splinter-amil convinces that it is not from 'milk' despite the fact that Lovamil is a milk brand for pregnant women, as it lacks of grapheme /a/ in neither love nor milk.

Blends fooshion and fashound, names of event, are interesting in the order of the source words. Both use source word 'fashion' yet the order is different, last and initial word, respectively. The order of the source words indicates the order of importance; the initial words represent events held, the second words suggest as supplementary.

The source words of proper name, Jogjakarta and Indonesia, in Jogjacation and Idenesia, are also put in different order. The pronunciation of the second blend will be awkward should Indonesia become the initial source words.

In this sub-class, there are 2 blends with Latin source form: socio- and anthropo- Whereas in the sociophoria, the clipped form socio- is from Sociology, a department in a Political Science Faculty that holds the happy event, the source form socio- in blend sociopreneur, is a prefix or combining form. The source bound root anthropo- is from 'anthropology'. There are 2 blends in this table that undergoes multiple processes. The blend ebotec consists of 3 sources, one of which is an acronym ELINS, Electronics and Instrumentation, a program study at Universitas Gadjah Mada. This formation process could fall into acronym because the one retained in the first and the third source are only the first graphemes, /e/ from ELINS and/c/ from 'competition'. However, the fact that the second syllable from the second source is kept /bot/ keeps this formation a blend. In order the new formation pronounceable the vowel /e/ is inserted between the second clipped form and the grapheme /c/. Almost similar is Chernival, this blend undergoes blending process twice: the first syllable "Cher" is from ch(emical) e(-ca)r which is Chem(ical) E(ngineering) Car Competition held at Institut Teknologi Surabaya. Besides competition, they also used shortened "carnival" to name the event.

Instead of combining the final splinter, pasco uses the second syllable and results in Indonesian pronunciation rather than English: /pastjo/ not/pasko/. Although tusning follows the rule of initial splinter combined with final splinter, the process has changed the orthography of Tues to Tus by dropping grapheme /e/ as they are pronounced almost the same in Bahasa Indonesia.

b. Both splinters are the beginning of words: acetal$\operatorname{acet}(\mathrm{yl})+\operatorname{al}(\mathrm{cohol})$

\begin{tabular}{|c|c|c|}
\hline blends & & Constituents and process \\
\hline Capcin & $\longrightarrow$ & $\operatorname{Cap}($ pucino $)+\operatorname{cin}(\mathrm{cau}) *$ \\
\hline Buavita & $\rightarrow$ & $\operatorname{Bua}(\mathrm{h}) *+\operatorname{vita}(\min )$ \\
\hline Sadis & $\rightarrow$ & $S a$ (turday) $+\operatorname{dis}($ hes $)$ \\
\hline Cheеро & - & Chee(sy) + po(tato $)$ \\
\hline Fantasteen & $\rightarrow$ & $\operatorname{Fantas}(\mathrm{y})+\operatorname{teen}($ ager$)$ \\
\hline Femfest & $\longrightarrow$ & Fem(inist) + fest(ival ) \\
\hline Robocon & $\rightarrow$ & $\operatorname{Robo}(\mathrm{t})+\operatorname{con}($ test $)$ \\
\hline
\end{tabular}

In this sub-type, there are 2 blends containing BI source word: 'cincau' (grass jelly) and 'buah' (fruit). The pronunciation of 'capcin' is / t $4 \mathrm{pt} \mathrm{f} \mathrm{in} /$, moreover, its second syllable is pronounced the same with that from the third of 'cappucino'. The splinter vita in 'buavita' is from 'vitamin' and pronounced Indonesian way /vit $/$. It is also found 1 English-like Indonesian word sadis (from English loanword 'sadistic') which is actually a blend whose source words are both English: 'Saturday' and 'dish.' The meaning of the 
blend is completely different from the meaning of the compound. This blend is intentionally coined to be posted on a poster to be eye-catching. Passer-by then can connect the message of the word/blend sadis with the picture of the poster, displaying a chef holding a big and sharp knife cutting steak, the special dish offered on Saturday evenings at a hotel restaurant.

c. Either the beginning or the end of splinter is embedded in a discontinuous splinter (with some reduction in either splinter): autopathography - auto(bio)graphy + patho $(\log y)$

$\begin{array}{lll}\text { blends } & & \text { Constituents and process } \\ \text { Narture } & \rightarrow & \mathrm{N}(\text { at)ure }+\underline{\text { art }} \\ \text { Imaginightion } & \rightarrow & \text { Imagi(nat)ion }+\underline{\text { night }} \\ \text { Refoodlution } & \rightarrow & \operatorname{Re}(\text { vo)lution }+\underline{\text { food }}\end{array}$

There are three data belonging to this sub-class of which a splinter of the first source words are replaced by the second source word whose sounds, to Indonesians, are similar to the clipped splinters: /at/ and /art/; /nat/ and /night/; and /vo/ and /food/ which actually are distinct from each other.

\section{Partial blends}

Partial blends in which only one source word is reduced

a. The full word is followed by a splinter : bloggerific - blogger + (terr)ific

\begin{tabular}{|c|c|c|}
\hline blends & & Constituents and process \\
\hline Sweetylicious & $\rightarrow$ & Sweety $+($ de $)$ licious \\
\hline Snacklicious & $\longrightarrow$ & Snack $+($ de $)$ licious \\
\hline Rubylicious & $\rightarrow$ & Ruby $+(\mathrm{de})$ licious \\
\hline Cafelicious & $\rightarrow$ & Café + (de)licious \\
\hline Selfielicious & $\rightarrow$ & Selfie $+($ de)licious \\
\hline Artscape & $\rightarrow$ & Art $+(\mathrm{e})$ scape or (land)scape \\
\hline Artspiration & $\rightarrow$ & Art + (a)spiration \\
\hline Art-griculture & $\rightarrow$ & Art + (a)griculture \\
\hline Artventure & $\longrightarrow$ & Art $+(\mathrm{ad})$ venture \\
\hline Eggventure & $\rightarrow$ & Egg $+(\mathrm{ad})$ venture \\
\hline Soundsations & $\rightarrow$ & Sound $+($ sen $)$ sations \\
\hline Creativepreneur & $\rightarrow$ & Creative + (entre)preneur \\
\hline Foodpreneur & $\rightarrow$ & Food + (entre)preneur \\
\hline Popstalgia & $\rightarrow$ & Pop $+($ no)stalgia \\
\hline Rockstalgia & $\rightarrow$ & Rock + (no)stalgia \\
\hline
\end{tabular}

$\begin{array}{ll}\text { Folkamartani } & \rightarrow \text { Folk }+(\text { mino }) \text { martani } \\ \text { Youthgether } & \rightarrow \text { Youth }+(\text { to }) \text { gether } \\ \text { Earthernity } & \rightarrow \text { Earth }+(\text { et }) \text { ernity } \\ \text { Coffeenection } & \rightarrow \text { Coffee }+(\text { con }) \text { nection } \\ \text { Wine'tastic } & \rightarrow \text { Wine' }+(\text { fan }) \text { tastic } \\ \text { heteroddicted } & \longrightarrow \text { Hetero }+(\text { a }) \text { ddicted } \\ \text { Hydrococo } & \rightarrow \text { hydro }+ \text { coco }(\text { nut })\end{array}$

In this sub-type, there are 5 noun + adjective blends with the over-use adjective splinter -licious, which is even regarded as a morpheme (Algeo 1977: 52, Mottiello, 2013: 117) and thus, its combination is regarded more as compound not blends. However these compounds do not follow the rule of English adjective + noun but rather of Indonesian. In the above data, all of the final source words are adjective 'delicious'. Another sample of noun + adjective is winetastic.

In terms of duplicating, final splinters-venture, -preneur, -stalgia are among popular final splinters found in this research. In the data, the initial word 'art' is often combined with other words. Most of them are in initial position, there is one though in final position (see the next table: dedicart). This shows how blend formation is easily duplicated.

Only one blend that complies with English adjective + noun combination: with the noun as the head: creativepreneur. In this sub-type, there is one blend with bound root hetero- functioning like prefix to the adjective 'addicted.'

In forming blend folkamartani vowel /a/ is added in between the full intial word 'folk' and the splinter martani a clipped name of a place in Yogya: Minomartani.

b. The full word is preceded by a splinter

$$
\begin{array}{ll}
\text { blend } & \text { Constituents }+ \text { process } \\
\text { Kalimilk } & \rightarrow \text { Kali(urang })+ \text { milk } \\
\text { Ngayogbook } & \longrightarrow \text { Ngayog(yokarto) }+ \text { book } \\
\text { Ngayogjazz } & \longrightarrow \text { Ngayog(yokarto })+ \text { jazz } \\
\text { Metamormovies } & \longrightarrow \text { Metamor(phosis })+ \text { movies } \\
\text { Dedicart } & \longrightarrow \text { Dedic(ation })+ \text { art }
\end{array}
$$

Two initial source words are proper names of place: Kaliurang and Ngayogyakarta, other name of Yogyakarta or Jogjakarta. The clipped parts are mostly syllables. Interestingly, Ngayogyakarta is clipped in 
the same part in the two blends.

c. The full word is intercalated within a discontinuous splinter : cewebrity - ce(le)brity + web; but also adorkable—adorable + dork

$$
\begin{array}{ll}
\text { blends } & \text { Constituents and process } \\
\text { AMAYzing } & \rightarrow \text { Amazing }+\underline{\text { May }} \\
\text { JogjaRockarta } & \rightarrow \text { Jogjakarta }+ \text { rock } \\
\text { Narture } & \rightarrow \text { N(at)ure }+\underline{\text { art }} \\
\text { Imaginightion } & \rightarrow \text { Imagi(nat)ion }+\underline{\text { night }} \\
\text { Refoodlution } & \rightarrow \text { Re(vo)lution }+\underline{\mathbf{f o o d}}
\end{array}
$$

The second source words in this sub-type are inserted in the initial with or without a cut in the initial. In Jogjarockarta, there is no cut in either first nor second resource word, but overlap graphame $/ \mathrm{k} /$. In imaginightion, the vowel /a/ in the third syllable of the initial is clipped. In refoodlution, the consonant $/ \mathrm{v} /$ is deleted overlapped fully with second source word.

\section{Morphonological and graphical formation}

\section{Overlapping}

a. Overlap both graphically and phonologically with no other shortening: anecdotage - anecdot + dotage

Except lobsterrific which is a noun-adjective combination, the other blends in this sub-type are noun-noun combinations. See table 1.

It can be seen that the extent of constituents overlapped is varied, from a single phoneme: $/ \mathrm{r} /$ in guitarun, /1/ specialive, / $\mathrm{t} /$ in artourism, $/ \mathrm{n} / \mathrm{in}$ iconinety and $/ \mathrm{k} /$ in Jogjarockarta to several: two phonemes /ma/in aMayzing and maygic, a syllable / ter/ in lobsterrific and soulotions /soul/ that sounds similar with the overlapped constituent of /sol/. The initial full word of supersemarch is actualy an Indonesian acronym: Surat Perintah Sebelas Maret ( a decree signed by the first Indonesian president, on 11 March, that led Suharto, the second one, came to power as his successor).

b. The constituent overlap both graphically and phonologically with shortening at least one of them: compfusion - comp(uter) + co(n)fusion

Generally the constituents overlapped are single similar graphemes (see table 2); however, there are two blends with different grapheme overlapped /f/ and $/ \mathrm{v} /$ and $/ \mathrm{sh} /$ and $/ \mathrm{s} /$; but phonetically they are regarded the same. Yet, /at/ in 'nature' and that in 'art' are almost similar grapheme, to Indonesia they are hardly pronounced differently. Although, 'tolerance' and 'run' share grapheme $/ \mathrm{r} /$, the pronounciation of

\begin{tabular}{|c|c|c|}
\hline blends & Constituents and process & Constituent overlapped \\
\hline AMAYzing & Amazing + May & $/ \mathrm{ma} /$ \\
\hline Maygic (night) & $\underline{\text { May }}+$ magic & $/ \mathrm{ma} /$ \\
\hline Guitarun & Guitar + run & $/ \mathrm{r} /$ \\
\hline Specialive & Special + live & $/ 1 /$ \\
\hline Jogjarockarta & Jogjakarta + rock & $/ \mathrm{k} /$ \\
\hline Soulutions* & $\underline{\text { Soul }}+\underline{\text { solutions }}$ & $\begin{array}{l}\text { /Soul/ and /sol/ to Indonesian are almost phonologically } \\
\text { similar }\end{array}$ \\
\hline Artourism & Art + tourism & $/ \mathrm{t} /$ \\
\hline Motivasinger & Motivasi $+\underline{\text { singer }}$ & $/ \mathrm{si} /$ \\
\hline Supersemarch & Supersemar $+\underline{\text { march }}$ & $/ \mathrm{mar} /$ \\
\hline Iconinety (9) & Icon + ninety & $/ \mathrm{n} /$ \\
\hline Lobsterrific & Lobster + terrific & $/$ ter/ \\
\hline
\end{tabular}
splinter-rance is replaced the morpheme of 'run' . Bahasa Indonesia has the assimilated English tolerance 'toleran' whose final syllable is pronounced /-r $\wedge \mathrm{n} /$ similar to that of 'run'. There are 3 adjective blends: 'sempolicious', 'FIBulous' and 'sluurprising' two of which with noun initials: 'sempol' ( a local snack) and FIB ( a proper name). The interesting thing is the initial source word of sluurprising that gives onomatopaeic emphasis on its original word by giving extra vowel $/ \mathrm{u} /$. The blend is a combination of verb and

Table 1. 
Table 2.

\begin{tabular}{|c|c|c|c|}
\hline blends & Constituents and process & Constituent overlapped & Constituent shortened \\
\hline Medicare & Medic $($ al $)+\underline{\text { care }}$ & $/ \mathrm{c} /$ & $-\mathrm{al}$ \\
\hline Biolympic & Biol(ogy) + olympic & $/ \mathrm{o} /$ and $/ 1 /$ & -ogy \\
\hline Javabica & $\mathrm{Jav} \underline{\mathbf{a}}+(\mathrm{ar}) \underline{\mathbf{a b i c a}}$ & $/ \mathrm{a} /$ & ar- \\
\hline Bassaurus & Bass + (dino) $\underline{\text { saurus }}$ & $/ \mathrm{s} /$ & dino- \\
\hline Soundrenaline & Sound + (a)吕renaline- & $/ \mathrm{d} /$ & a- \\
\hline Lobstreet & Lob $\underline{s t}(\mathrm{er})+\underline{\text { street }}$ & $/ \mathrm{st} /$ & -er \\
\hline Sempolicious & Sempol $+(\mathrm{de}) \underline{\text { icious }}$ & $/ 1 /$ & de- \\
\hline FIBulous & FIB + (fa) $\underline{b}$ ulous & $/ \mathrm{b} /$ & fa- \\
\hline sluurprising & Sluurp $+(\mathrm{su})$ rprising & $/ \mathrm{rp} /$ & su- \\
\hline MUFaganza & MUF + (extra)ㅁaganza & $/ \mathrm{v} / \rightarrow / \mathrm{f} /$ & extra- \\
\hline Fashound & Fash(ion) + sound & $/ \mathrm{sh} /$ and $/ \mathrm{s} / \rightarrow / \mathrm{J} /$ & -ion \\
\hline Narture & Nature $+\underline{\text { art }}$ & $/ \mathrm{e} / \mathrm{h} \rightarrow \mathrm{a}: \mathrm{t} /$ and $/ \mathrm{t} /$ & $-r-$ \\
\hline Tolerun & Toler $($ ance $)+\underline{\text { Run }}$ & $\begin{array}{l}/ \mathrm{r} / \\
/ \text {-rəns/ } \rightarrow / \mathrm{r} \wedge \mathrm{n} /\end{array}$ & -ance \\
\hline
\end{tabular}

Table 3.

\begin{tabular}{|c|c|c|}
\hline blend & Formation process & Phonological overlap \\
\hline Cultourism & Culture $+\underline{\text { tourism }}$ & $\begin{array}{l}\text { /ture/ and /tour/ } \\
\text { / t } \int ə r / \text { and /tuər/ }\end{array}$ \\
\hline Eggsperience & Egg + experience & $\begin{array}{l}\text { /gs/ and /ex/ } \\
\text { /egs/ and //k's/ }\end{array}$ \\
\hline Coolinary & $\underline{\text { Cool }}+\underline{\text { culinary }}$ & $\begin{array}{l}\text { /cool/ and /cul/ } \\
/ \text { ku:l/ and /ksl/ }\end{array}$ \\
\hline Soulutions & $\underline{\text { Soul }}+\underline{\text { solutions }}$ & $\begin{array}{l}\text { /soul/ and /sol-/ } \\
\text { /səol// and /sa'l/ }\end{array}$ \\
\hline Salebrate & $\underline{\text { Sale }}+\underline{\text { celebrate }}$ & $\begin{array}{l}/ \text { sale/ and /cele-/ } \\
\text { /seil/ and /sa'l/ }\end{array}$ \\
\hline Eatereview & Eatery $+\underline{\text { review }}$ & $\begin{array}{l}/ \mathrm{ry} / \text { and } / \mathrm{re} / \\
/ \mathrm{ri} / \text { and } / \mathrm{rI} /\end{array}$ \\
\hline
\end{tabular}

adjective, which is actually uncommon combination, resulting in a look alike present participle adjective.

There are 2 blends with acronym initials FIB (Fakultas Ilmu Budaya, Faculty of Cultural Sciences at Universitas Gadjah Mada) followed by an adjective (fabulous) and MUF (Mandiri Utama Finance) followed by noun (extravaganza). Originally, FIB and MUF are abbreviations, but for this blending purpose, they are pronounced as words /fib/ and /muf/.

c. The constituent overlap phonologically but not orthographically: buyography — buy + biography
Although the overlap is not phonologically the same, they are very close and to Indonesians (see table 3), they are regarded as similar, for example / cool/ and /cul/ in 'culinary'. However, the choice of which splinter's pronunciation to be chosen in the new blend is not always the same; the easier pronunciation of the splinter the bigger chance to be chosen as the sound of the blend. For example, the blend soulutions, the first syllable is possibly pronounced by Indonesian as the first splinter of the second word source as / sa'l/ rather than /savl/ ; however, for cultourism the second syllable of the blend will likely be pronounced 
/ t $\int$ ər/ rather than /tuər/. To Indonesian, English single vowel is possibly easier than dipthongs. The bold pronunciation of the overlapped constituents are possibly the ones chosen to pronounce the blends. To Indonesian learners of English, pronunciation gives them problems and this sentiment is used by the current research to draw this preliminary conclusion, this part of the study needs further research.

\section{Non-overlapping}

Neither phonological nor orthographical overlap takes place in the blends: Calexico - Cal(ifornia) $+(\mathrm{M})$ exico

The data classified under this can be observed in part 1.a-b, and 2.a-b above.

\section{Morphosemantic}

\section{Attributive blend}

This type of blends is similar to endocentric compound in which the second word source is the head and its relation is transparent. However, in this research, the original compounds of the blends are not always right-headed. The following is the right-headed and left-headed blends found in the research.

a. Left-headed attributive blends.

\begin{tabular}{|c|c|c|}
\hline Blends & & Constituents \\
\hline Chitato & $\rightarrow$ & Chips + potato \\
\hline Idenesia & $\rightarrow$ & Idea + Indonesia \\
\hline Iconinety9 & $\rightarrow$ & Icon + ninety 9 \\
\hline maygic & $\rightarrow$ & May + magic \\
\hline Bassaurus & $\rightarrow$ & Bass + dinosaurus \\
\hline Sweetylicious* & $\rightarrow$ & Sweety + delicious \\
\hline FIBulous & $\rightarrow$ & FIB + fabulous \\
\hline sluurprising & $\rightarrow$ & Sluurp + surprising \\
\hline Wine'tastic & $\rightarrow$ & Wine + fantastic \\
\hline lobsterrific & $\rightarrow$ & Lobster + terrific \\
\hline salebrate & $\rightarrow$ & Sale + celebrate \\
\hline youthgether & $\rightarrow$ & Youth + together \\
\hline
\end{tabular}

This type of blends is similar to endocentric compound in which the second word source is the head and its relation is transparent. However, in this research, the original compounds of the blends are not always right-headed. Many of the blends are left-headed; it is understandable, because most of Indonesian compounds are left-headed, for example: keripik (chips) + kentang (potato) and not kentang keripik.
The following is some samples of left-headed and right-headed blends found in the research.

In the data, there are 5 noun blends consisting of noun + noun combination whose first noun functions as semantic heads and the second noun, on the right, as the modifier. There are 6 adjective blends, besides sweetylicious, using adjective 'delicious' and there are other 4 adjective blends with all the adjective in the right and the heads are nouns in the left side. This formation type (noun + adjective) is a common formation of Indonesian adjective-noun phrase: “ FIB keren" (FIB fabulous) rather than "keren FIB" (fabulous FIB). There is also a verb-like salebrate and an adverb-like youthgether.

The nature of most of these blends is endocentric, for example chitato is "chips from potato,' and bassaurus is music event using powerful bass guitars, as powerful as a dinosaurus. Whereas, wine 'tastic is understood as 'fantastic wine' or 'wine that is fantastic' whose two source words exhibit endocentric relationship, sluurprising blend, however, exhibits exocentric relationship whose semantic head 'beverage' is outside. Another exocentric blend is Maygic whose semantic head 'night' is outside. In terms of form, even when it is pronounced by Indonesian, salebrate is like the verb 'celebrate', but shoppers most likely understand it 'a sale to celebrate a particular holiday' rather than 'celebrate a sale.' Almost similar is the adverb-like youthgether that likely means 'young people get together'.

b. Right-headed attributive blends

$\begin{array}{ll}\text { Blends } & \text { Constituents } \\ \text { Jogjacation } & \rightarrow \text { Jogjakarta }+ \text { education } \\ \text { sociophoria } & \rightarrow \text { Sociology }+ \text { euphoria } \\ \text { sociopreneur } & \rightarrow \text { Socio }+ \text { entrepreneur } \\ \text { ebotec } & \rightarrow \text { ELINS }+ \text { Robot }+ \text { e-Competition } \\ \text { Chernival } & \rightarrow \text { Chemical }+ \text { e-car }+ \text { carnival } \\ \text { pasco } & \rightarrow \text { Passion }+ \text { chocolate } \\ \text { instafluences } & \rightarrow \text { Instagram }+ \text { influences } \\ \text { agriventor } & \rightarrow \text { Agriculture }+ \text { inventor } \\ \text { anthropocene } & \rightarrow \text { Anthropology }+ \text { scene } \\ \text { Goviesta } & \rightarrow \text { Government }+ \text { Fiesta } \\ \text { Tusning } & \rightarrow \text { Tuesday }+ \text { evening } \\ \text { artscape } & \rightarrow \text { Art }+ \text { escape } \\ \text { artspiration } & \rightarrow \text { Art }+ \text { aspiration }\end{array}$




\begin{tabular}{|c|c|c|}
\hline artgriculture & $\longrightarrow$ & Art + agriculture \\
\hline eggsperience & $\rightarrow$ & Eggs + experience \\
\hline eggventure & $\rightarrow$ & Egg + adventure \\
\hline foodpreneur & $\longrightarrow$ & Food + entrepreneur \\
\hline soundsations & $\longrightarrow$ & Sound + sensations \\
\hline soundrenaline & $\rightarrow$ & Sound + adrenalin \\
\hline popstalgia & $\rightarrow$ & Pop + nostalgia \\
\hline Javabica & $\rightarrow$ & Java + arabica \\
\hline Folkamartani & $\rightarrow$ & Folk + Minomartini \\
\hline Earthernity & $\rightarrow$ & Earth + eternity \\
\hline Coffeenection & $\rightarrow$ & Coffee + connection \\
\hline Kalimilk & $\rightarrow$ & Kaliurang + Milk \\
\hline Tolerun & $\rightarrow$ & Tolerance + Run \\
\hline Ngayogbook & $\rightarrow$ & Ngayogyokarto + book \\
\hline Ngayogjazz & $\rightarrow$ & Ngayogyokarto + jazz \\
\hline metamormovies & $\rightarrow$ & Metamorphosis + movies \\
\hline cultourism & $\longrightarrow$ & Culture + tourism \\
\hline biolympic & $\rightarrow$ & Biology + Olympic \\
\hline dedicart & $\rightarrow$ & Dedication + art \\
\hline lobstreet & $\rightarrow$ & Lobster + street \\
\hline eatereview & $\rightarrow$ & Eatery + review \\
\hline heteroddicted & $\rightarrow$ & Hetero + addicted \\
\hline specialive & $\rightarrow$ & Special + live \\
\hline medicare & $\rightarrow$ & Medical+ care \\
\hline creativepreneur & $\rightarrow$ & Creative + entrepreneur \\
\hline Motivasinger & $\rightarrow$ & Motivasi + singer \\
\hline Lovamil & $\rightarrow$ & Love + hamil \\
\hline narture & $\rightarrow$ & Nature + art \\
\hline imaginightion & $\longrightarrow$ & Imagination + night \\
\hline refoodlution & $\longrightarrow$ & Revolution + food \\
\hline
\end{tabular}

Compared to that of the left-headed blends, there are more of right-headed blends in the data. Most of them are noun + noun combinations; however, there are some of those with adjectives, for example: the semantic right head addicted is preceded by a combining form 'hetero'. Unlike the combination noun + adjective shown in the previous table, in this sub-class, to semantically mean the same, the combination used is adjective + noun: creativepreneur, specialive, medicare. It is clear the right heads syntactically determine the word class of the blends.

There are 2 blends using Indonesian words 'motivasi' the assimilated version of 'motivation' and 'hamil' meaning pregnant. The data also have proper names of place as one of the source word: Ngayogyokarto/Jogjakarta, Kaliurang, and Minomartani.

Semantically, they are all attributive, for example Jogjarockarta; rock concert in Jogja, another name Yogyakarta, similar to that of Ngayogjazz another attributive blend meaning 'Jazz concert in Yogyakarta' which sometimes is called, Ngayogya shortened from Ngayogyakarta

Most attributive right-headed blends in the table exhibit endocentric relationship between the source words of which the second word functions as a semantic head and the first one as the modifier. The meaning of the noun + noun blends are transparent, for example: chernival means a carnival of e-car held by Chemistry department at a Surabaya-based engineering university; coffeenection may mean establishing connection with people who share the same interest in coffee or javabica means coffee (of Arabica type) that comes from Java. Whereas creativepreneur means entrepreneur who is creative, foodpreneur can be understood as entrepreneur focussing on food.

There are 3 blends whose first word source is 'art' in contrast with one blend whose second source word is 'art'. Whereas artspiration, for example, may mean aspiration people get from art, dedicart may mean art for dedication or that dedicated to someone. Furthermore, artscape can be interpreted as escape from something to enjoy art, and artgriculture can be understood the agriculture students hold art performance.

The above possible meaning of these blends indicate the word creator's intention of playing with words to create funny, attractive, memorable blends. Like those using 'delicious', 'entrepreneur, ' the use of 'art, street, live', and some others either as heads or as modifier in creating blends, despite its lack of creativity, seem common in neologism, creating new words.

\section{2. coordinate blends}

Like coordinate compound whose source words are heads of equal importance, so does the coordinate blend.

$\begin{array}{lll}\text { chocoberry } & \longrightarrow & \text { Chocolate }+ \text { strawberry } \\ \text { robominton } & \longrightarrow & \text { Robot }+ \text { badminton } \\ \text { Fooshion } & \longrightarrow & \text { Food }+ \text { fashion }\end{array}$




$\begin{array}{lll}\text { Fashound } & \rightarrow & \text { Fashion }+ \text { sound } \\ \text { Capcin } & \rightarrow & \text { Cappuccino }+ \text { cincau } * \\ \text { Artventure } & \rightarrow & \text { Art }+ \text { adventure } \\ \text { Artourism } & \rightarrow & \text { Art }+ \text { tourism } \\ \text { Motivasinger* } & \rightarrow & \text { Motivator }+ \text { singer }\end{array}$

There is one blend motivasinger whose source words could possibly be motivasi + singer, or motivator + singer. Whereas, the former blend includes an assimilated word, the latter use both English source word, despite the fact that 'motivator' is also borrowed in Bahasa Indonesia. If the latter is the case, the blend is a blend: someone who is a singer and at the same a motivator (appositional compound, Plag 2002, p. 188). In this category, there is another blend using an Indonesian word 'cincau' grass-jelly.

When motivasinger is from motivasi + singer, it is endocentric, the other blends are exoteric whose heads are outside the blend. For example: 'Fooshion market' and Robominton competition; a competition of making robot and of badminton.

Despite the different order of the source words, semantic explanation of fooshion and fashound is that they are events of food and fashion in fooshion and fashion and sound representing musical performance in fashound. The reason behind this possibly because each event has its own emphasis, the former on food, and the latter on fashion. Besides, each blend phonologically sounds similar to the words that relate to each event each blend represents. The pronunciation of fooshion, to Indonesian, is close to 'fusion' which reminds us of fusion food; whereas fashound sounds similar to 'fashion'. The source words 'art', however, are positioned at the left in both blends and have equal importance to the right source words.

\section{CONCLUSION}

This research found that morphotactically, the data can be classified into total and partial blend. In the subclassification of total blend, the data can be classified into initial splinter of the first source word + final splinter of the second source, with one exception of Pasco, whose final splinter is the mid splinter of the three-syllable word 'chocolate'. Some data can be classified into total blends consisting of both initials of the source words. In this sub-category, there are two blends with Indonesian noun source word in each, 'cincau' the second source word of capcin, and 'buah', the first source word of buavita. This different order of Indonesian words in the combinations seems intentional: cappucinno with 'cincau' (jelly grass) and vitamin made from 'buah' (fruit). Few data fit the subcategory in which either the initial or the end of splinter is embedded in a discontinuous splinter. In partial blends, there are more blends whose first source words are kept full and followed by clipped second source word.

In morphonological and graphical formation, there is no non-overlapping blend. There are graphically and phonologically overlapping blends with no shortening and that with shortening. The constituents overlapped are from single phoneme to a syllable. In this sub-category, there are a few blends with Indonesian initials: 'sempol', and 2 abbreviations that turn into acronyms in the blends: FIB and MUF. Phonological, but not orthographical, overlap also takes place, especially in syllables whose English and Indonesian' sounds are similar, for example to Indonesia /cool/ and /cul sound similar, therefore phonological overlap is possible.

Morpho-Semantically, attributive blends are more frequent than the coordinative ones. Although understandably, there are more right-headed blends, there are also some left-headed blends that could be influenced by Indonesian word combination rule. The semantic relations of these right-headed blends are endocentrics, whereas in the left-headed there could also be also exocentric blends, especially when the head words are adjective. The coordinate blends whose source words are equal in importance as heads are also likely exocentric.

\section{REFERENCES}

Algeo, J. (1977). Blends, a structural and systemic view. American Speech, 52(1-2), 47-64.

Belieava, N. (2014). A study of English Blend: from strcture to meaning and back again. Word Structures, 7(1), 29-54.

Belieava, N. (no date). The power of slanguage: form and meaning of English blends (ppt). Url: www2.unisiegen.de/-engspra/draem/Beliaeva-ppt.pdf

Carstairs-McCarthy, A. (2002). An Introduction to English Morphology: Words and Their Structure. Edinburgh: Edinburgh University Press.

Danks, D. (2003). Separating Blends: A Formal Investigation of the Blending Process in English nd Its Relationship to Associated Word Formation Processes (a Thesis). University of Liverpool.

Fandrych, Ingrid. (2008). Submorphemic elements in the formation of acronyms, blends and clippings. Lexis: Journal in English Lexicology, 2, 105 - 123.

Gries, S.T. (2004). Some characteristics of english morphological blends. A paper downloaded from http://citeseercx.ist.psu.edu/viewdoc/downoad?doi 
$+10.1 .1 .78 .1181 \&$ rep $=1 \&$ type $=$ pdf

Gries, S.T. (2004). Shouldn’t it be breakfunch. Linguistics, 42(3), 639-667.

Hosseinzadeh, N. M. (2014). New blends in English Language. International Journal of English Language and Linguistics Research, 2(2), $15-26$.

Kemmer, R. Types of word formation processes (Ling/Engl 215 course information). Retrieved from http://www. ruf.rice.edu/kemmer/words/wordtypes.html.

Mattiello, E. (2008). An Introduction to English Slang: a Description of its Morphology, Semantics, and Sociology. Milano: Polimetrica.

Mattiello, E. (2013). Extra-Grammatical Morphology in English. Berlin: De Gruyter Mouton.
Pedrosa-Trias, S. (2013). Are there coordinate compound. On-line Proceedings of Mediterranean Morphology Meeting, Centre de Linguistica Teorica, UAB. Retrieved from http://www.lilec.it/mmm/wp/wpcontent/uploads/2013/98-111-Padrosa-Trias.pdf.

Permatasari and Suyudi (2011). The Patterns of Indonesian Blends. Proceeding of Uzbek_Indonesian Joint International Conference, 23-26. Gunadarma University, Jakarta 18 October 2011.

Plag, I. (2002). Word Formation in English. Cambridge University Press: a draft version.

Quirk, R., Greenbaum, S., Leech, G. and Svartvik, J. (1985). A Comprehensive Grammar of Englsh Grammar. Longman. 